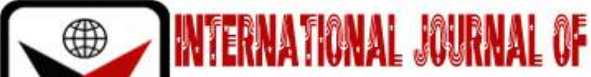

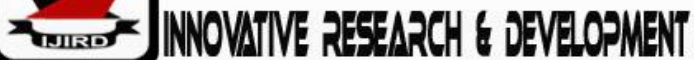

ISSN 2278 - 0211 (Online)

\section{The Effect of Auditor Tenure on Audit Independence in Botswana}

Sihlobo Nyoni
Accounting and Finance Lecturer, Department of Accounting and Finance,
Ba Isago University, Botswana
Collen Tichaona Mahambo
Accounting and Finance Lecturer, Department of Accounting and Finance,
Ba Isago University, Botswana

\begin{abstract}
:
The main objective of this study is to find out the perceived influence of timeframe of auditor on audit independence. It also helps to find out whether audit firm rotation should be familiarized in Botswana or not. The main objective of this study is to investigate the effect that auditor tenure has on audit independence. The sample had been drawn from Botswana Stock exchange based on the list of accredited auditors and listed companies. Descriptive research design has been applied on a sample of 3 Accounting Firms and 12 Accountants. Data collected was analysed using statistical analyses software package, SPSS version 21 in order to determine the audit independence level in relation to audit tenure. Audit independence was determined from the analysis of different factors affecting audit independency, frequency tables where used to analyse the responses of the sample population. The findings proved that a prolonged Audit tenure results in impaired audit independence. It was recommended that there is need to develop alternative measures to safeguard auditor's independence.
\end{abstract}

Keywords: Audit tenure, audit independence, agency theory

\section{Background of the Study}

Investors continue to loose their investment due to weak form of market effeciency in providing investment information. The Audit function cannot be spared as a key involved party. The primary concerned areaa is the internal control weaknesses, disagreements on accoounting, inability to rely on management, scope limitation, unauthorised opinion, and illegal acts. The refelection of theses types of deficiences seen on company's accounting and Audit system which in the long run hampered the reported financial results. Independence impared and cost reduction reasons could have implications for the audit hence the need for change of auditor arises.

As a way of mitigting such challenges, mandatory audit firm rotation has been welcomed by the Botswana Accountancy Oversight Authority (BAOA) with effective from 1st January 2019 (BAOA, 2019). BAOA went on to agree on terms of MAFR after considering and consulting with its local stakeholders who are mainly the Public Interest Entities (PIEs), its regional peers in South Africa and Mauritius, and eventually, internationally with its European Union and United Kingdom counterparts who all have already adopted MAFR. The shortage of accounting and auditing skills in Botswana ahd been highlighted by the MAFR adoption, BAOA (2019). They recommended that there should be no rotation of senior audit staff other than the Engagement Quality Control Review (EQCR), and the lead partner.

Proponents of mandatory audit firm rotation argue that long-tenure relationships between audit firms and clients can lead to audit failures due t o high levels of familiarity that impair auditors' independence and professional skepticism (Moore et al. 2006, Gavious, 2007).

Opponents of mandatory audit fim rotation argue that long tenure auditor-client relationships lead to valuable client and industry specific knowledge over time resulting in enhanced audit quality. Short tenure may be problematic as audit firms try to build relationships with their clients, and mandatory rotation likely would be a hinderance to such a relationship (PCAOB 2011b, 2011c). A lack of familiarity may have adverse consequences, which could be exacerbated by insituting mandatory audit firm rotation (Roush et al, 2011). The primary purpose of this study is to investgate Botswana corporate community's perspective on the issue of the recent changes in the Auditor tenure and how it impacts on auditor independence and financial reporting quality. The researcher endeavors to improve the understanding of the underlying reasons behind the positions of audit committee members on mandatory audit firm rotation. The study also examines how audit committee members currently ensure auditor independence and objectivity and how audit committee chairs maintain and monitor a series of important relationships including the audit committee-external auditor relationship, the audit committee-financial management relationship, and the external auditor-financial management relationship. Finally the study explores audit committee members' views on the costs associated with switching audit firms. 


\section{Literature Review}

\section{1. Auditor Tenure}

The length of relationship between auditor-client is known as auditor tenure. A threat to independence can be noticed due to too long association between the auditor and his client. As a result less attentiveness can be noticed from auditors end. According to Watts and Zimerman (2006), more association between client and auditor hampers the quality checking which results in weaknesses of internal control and risk sources. Geiger and Raghunandan (2002), presented a different view by mentioening that the audit quality is relatively lower in the initial years of an auditor-client relationship, specifically, short tenure is positively associated with audit reporting failures. Concerns had bene rasided by Enron, WorldCom and Global Crossing regarding the role of the auditor. According to Chi (2010) and IFAC (2003), lack of audit independence creates decreased credibility for the financial information.

Arel et al (2005), also expressed concern regarding the lack of auditor independence. Other important organizations like IFAC and GAO have focused on mandatory audit firm rotation. Lack of proper auditing and quality checking can easily result in acceptance of destructive accounting and failure in detecting frauds (Myers et al, 2003). Many scholars had argued for mandatory audit firm rotation as it increases the auditor's independence, objectivity and create a fresh new viewpoint of the financial statements. Whereas, the opponents argue that it tends to increase costs for the companies' and lost knowledge about the business. As per Geiger and Raghunandan (2002), more common audit failure had been seen in the early years when the auditor is not familiar with the company.

\subsection{Theoretical Framework}

\subsubsection{Agency Theory}

Agency theory holds a central role in the audit literature. It describes the fundamental conflict between selfinterested managers and owners, when the former have the control of the firm but the latter bear most of the wealth effects. Jensen and Meckling (1976) original model illustrates this by describing how lower managerial stakes lead to increases in non-pecuniary spending by the managers as they do not fully internalise the costs. Agency problems of this kind generate agency costs. A key ingredient in their theory is that outside shareholders cannot without cost observe the managers' actions. While the model makes many restricting assumptions, the results are applicable to a more general setting as shown by the numerous theoretical and empirical articles that have followed Jensen and Meckling's work. A range of other mechanisms that either align the interests of the managers and owners or limit managerial discretion have been suggested to reduce agency costs. Francis and Wilson (2008) stated that the agency theory is used whenever the reason for auditor changes is related to the agency-related incentives for higher quality audit such as diffusion of ownership and owner-debt holder conflict. The type and the level of the agency costs (conflicts of interest) in the emerging markets may be different than those witnessed in the developed markets. According to Fan and Wong (2005) in the emerging markets it is difficult to reduce agency conflicts between controlling owners and the minority shareholders through conventional internal and external control mechanisms such as board of directors.

\subsubsection{Signalling Theory}

Signalling theory postulates that firms with good performance tend to make voluntary disclosures more readily, as doing so is regarded as an easy means of distinguishing themselves from others in the marketplace. Hence, we infer that voluntary disclosure is positively related to firm performance and audit independence (Morris, 1987).

To describe behaviour of two different parties with access of different information sampling theory is very useful. The sender (one party), should know the process of how to communicate. Whereas, the other party, the receiver, must know the art of interpretation. In case of audit literature, sampling theory holds a very strong position. Information asymmetry is present due to the fact that unlike firm, investors and customers do not know all the details of the company.

The innate nature of signalling theory in part helps elucidate its omnipresence. The perceptiveness of the theory, helps inattributing costs to information acquisition processes that resolve information asymmetries in a wide range of economic and social phenomena.

\subsection{Audit Independence}

The independence decision of the auditor throughout decision making is known as Audit Independence. Independence means influence-free, absence of any kind of biasness (Sweeney, 2004). The chance of being perceived as not being objective increases with an auditor's lack of independence(Deangelo, 2001). Sometimes companies show high tendency to pay a very good amount to auditors which may damage the auditor's independence (Frankel et al, 2002; Li \& Lin, 2005). Two levels have been identified by McMullen (2006). These two levels affect the quality of the audit process. Proper synchronization between both the internal audit and external audit, improves external auditors' independence from managerial influences or pressures enables audit committees to guarantee that indiscretions and financial misstatement observed by external auditors are reported. Bedard et al (2004), highlighted how the aggressive earnings management decreasesif audit committee can include a financial expert or an expert in corporate governance. Craswel, Stokes and Laughton (2002) discussed about the association between auditor independence with audit fee dependence.

\section{Research Methodology}

A descriptive research design was employed to identify the effects of auditor tenure on auditor independence. The study was qualitative and therefore a survey research method was used by the researchers. The survey method allows the 
collection of a large amount of data from a sizeable population in a highly economical way (McNeill, 2005). This research design helps to examine and explain the effect of auditor tenure on auditor independence.All listed companies and audit firms are the target population for this study. The pre-requisite from the sample is proper understanding of auditing, financial reporting and corporate governance. To implement this stratified random sampling has been adopted to fulfil research objectives. The sample size for the research was adapted from Saunders et al (2005). The sample size of 3 Audit Firms and 12 professional accountants out of 33 of the listed companies on the Botswana Stock Exchange was used. Data was collected through the use of structured questionnaires, in depth interviews with key personnel from the sampled companies and audit firms. The researchers used Statistical Package for Social Sciences (SPSS version 21.0) software to analyze the data obtained from the questionnaire. The data was presented inform of tables for easy understanding.

\section{Findings and Analysis}

The data was analysed in the context of secondary data which is data and facts that already exist and primary data was collected using questionaires. The data was organized and presented using frequency tables.

\begin{tabular}{|c|c|c|c|c|c|}
\hline \multicolumn{2}{|c|}{} & Frequency & Percent & $\begin{array}{c}\text { Valid } \\
\text { Percent }\end{array}$ & $\begin{array}{c}\text { Cumulative } \\
\text { Percent }\end{array}$ \\
\hline \multirow{3}{*}{ Valid } & $\begin{array}{c}\text { Tenure of engagement } \\
\text { Tenure of the audit } \\
\text { Partner }\end{array}$ & 10 & 66.7 & 66.7 & 66.7 \\
& 4 & 26.6 & 26.6 & 93.4 \\
\cline { 2 - 5 } & Number of clients/auditor & 1 & 6.7 & 6.7 & 100.0 \\
\cline { 2 - 6 } & Total & 15 & 100.0 & 100.0 & \\
\hline
\end{tabular}

Table 4.1: Factors That Affect Independence Most

Table 4.1 shows some of the factors affecting audit independence, on the tabled factors that affect auditor independence, $(66.7 \%)$ were in agreement that the tenure that the auditor engages one client has a significant influence on the quality of work performed on the client and consequently the independency is impaired.26.6\% are of the idea that, it is the tenure of the auditor partner not the audit firm that matters most while $6.7 \%$ subscribed to the notion that the number of clients that the auditor has determines the level of independence that the auditor exercises towards the client.

\begin{tabular}{|c|c|c|c|c|c|}
\hline \multicolumn{2}{|c|}{} & Frequency & Percent & Valid Percent & $\begin{array}{c}\text { Cumulative } \\
\text { Percent }\end{array}$ \\
\hline \multirow{3}{*}{ Valid } & $0-3$ & 2 & 13.3 & 13.3 & 13.3 \\
& $3-5$ & 7 & 46.7 & 46.7 & 60.0 \\
\cline { 2 - 5 } & $5-10$ & 6 & 40.0 & 40.0 & 100.0 \\
\cline { 2 - 5 } & Total & 15 & 100.0 & 100.0 & \\
\hline
\end{tabular}

Table 4.2: Number of Years Served by Current Auditor

Table 4.2 shows results on the number of years that the companies had retained the current auditor, $46.7 \%$ of the sample had retained the current auditor for a period of 3 to 5 years while $40 \%$ had retained the current auditor for a period of 5 - 10 this shows that most companies have a tendency of retaining the same auditor for longer periods of time.

\begin{tabular}{|c|c|c|c|c|c|}
\hline \multicolumn{2}{|c|}{} & Frequency & Percent & Valid Percent & $\begin{array}{c}\text { Cumulative } \\
\text { Percent }\end{array}$ \\
\hline \multirow{3}{*}{ Valid } & \begin{tabular}{c} 
After audit failure \\
\cline { 2 - 5 }
\end{tabular} & 6 & 60.0 & 60.0 & 60.0 \\
& When it becomes uneconomic & 2 & 20.0 & 20.0 & 80.0 \\
\cline { 2 - 5 } & $\begin{array}{c}\text { When the Auditor become too } \\
\text { familiar with client }\end{array}$ & 2 & 20.0 & 20.0 & 100.0 \\
\cline { 2 - 6 } & Total & 10 & 100.0 & 100.0 & \\
\hline
\end{tabular}

Table 4.3: Reasons Why Companies Change Auditor

Table 4.3 shows results of the 10 respondents who agreed to have changed auditors previously. Of the 10 respondents; $60 \%$ cited audit failure as the reason for change while other $20 \%$ apiece cited economic factors and familiarity as reasons for change of auditor as tabulated on the table above. Participants indicated that the most significant cost associated with changing auditors is the time and effort involved in the tendering process and in bringing a new auditor up to speed with client- and industry-specific knowledge.

Respondents were also asked if there were any cases of audit failures in their firms, $60 \%$ of the respondents said their companies once experienced Audit failures, of the $60 \%, 20 \%$ cited disagreement as the cause of failure while $40 \%$ cited limitation of scope as the cause of failure.

All the respondents were of the idea that the tenure of the auditor should be limited and 64.3\% supporting five year tenure while three $7.1 \%$ segments of the respondents picked 4; 6 and 8 years respectively as the ideal tenure for auditors to engage with a single client. $14 \%$ think 10 year tenure can be the best to strike a balance between the effects of the learning curve and diminishing returns. 


\section{Discussion}

The study results show that most companies on the BSE are maintaining the same auditors for longer periods beyond five years, the reasons given by respondents on retaining auditors, a great percentage of auditor changes are due to audit fees and to refresh the perspective of investors concerning the issue of independence. This is in accordance with the above literature which stated that auditor changes occur more frequently following receipt of a qualified opinion so as to try to improve their companies image with another auditor. The other reason was the desire to reduce audit fees so as to improve company performance by reducing company expenditures. Another major finding was that most companies did not have standing policies that governed the tenure of service of their audit committees. The effect of the auditor's tenure with one client is two-fold, firstly a very short tenure compromises audit quality due to auditor's lack of client's industry specific knowledge, while a very long tenure poses a threat to auditor independence due to relationships built with the client overtime that impair objectivity.Moreover familiarity may pose a threat on the thoroughness of the audit work performed.

\section{Conclusion and Recommendations}

The study concluded that a prolonged tenure for the auditor results in impaired auditor independence due to continuous interaction of the auditor with the company's management. The study also concluded that limiting auditor tenure rejuvenates investors' confidence in the companies' audit system through enhancing auditor independence.

In light with the above conclusions, the researchers recommend that Auditor tenure should be restricted to a period of at most 8 years with lead audit partner rotated in a period of not more than 3 years. This can strike the balance between auditor's time to get industry specific knowledge of client and at the same time eliminating complacence on the part of the auditor.

The auditor should be allowed to compete again for audit services after a period of not less than 5 years which is technically after the tenure chair of the audit committee who is presumed to be an independent non-executive director according to the recommendation by the several codes of corporate governance such as king 111, Sarbanes 0xley, and the OECD codes. The study did not include public interest enterprises such as medical aids, pension funds and insurance companies, the researchers recommend future studies to be carried out on these enterprises. Future research can also be done to empirically explore the added value for the audit client resulting from a long relationship with the auditor by examining the synergies that can develop between the audit committee, management and auditor.

\section{References}

i. Arel et al, (2005)) Auditing Principles: A system-based approach, 5th edition, eaglewood cliffs, New Jersey, Prentice Hall

ii. Bedard, J. Coulombe, D. and Courteau L. (2004) Audit Committee Effectiveness, Audit Quality and Earnings Management,

iii. Chi, (2010); The use of audit committee for monitoring Journal of Accounting and public policy vol13 pp121-139

iv. Deangelo, (2001) Empirical analysis of the economic demand for auditing in the initial public offering market Journal of Accounting Research vol37 225-238

v. Fan P.H. and Wong T.J. (2005) Ownership Structure, Agency Problems, and Auditor Choice

vi. Frankel, R.M., Johnson, M.F. and Nelson, K. K, (2002) The Relation Between Auditors' Fees for Non-Audit Services and Earnings Management MIT Sloan, Working Paper No. 4330-02

vii. Gavious, I. (2007). Alternative perspectives to deal with auditors' agency problem. Critical Perspectives on Accounting, 18(4), 451-467.

viii. Geiger M. A. and Raghunandan, K (2002) Auditor Tenure and Audit Reporting Failures Auditing: A Journal of Practice \& Theory, Vol. 21, No. 1, March 2002

ix. IFAC. (2003) Quality levels of predecessors and successor auditor evidence from the reasons reported by managers for changing auditors Working paper Business Finance pg. 243-261

x. Jensen, M. and Meckling, W. (2010) Theory of the Firm Harvard Business School Harvard University Press

xi. Knapp (2001), The relationship between going concern, opinion and auditor loss function Journal of Accounting research vol 36 pg. 143-156

xii. Majinda, D. (2019). Mandatory Audit Firm Rotation Guidance on Recommended Best Practice | BAOA-Botswana Accountancy Oversight Authority. Retrieved 10 December 2019

xiii. McMullen (2006) Auditing today, 5th edition Cincinnati South Western College Publishing.

xiv. McNeill, P., \& Chapman, S. (2005). Research methods. Psychology Press.

xv. Michael Spence in (1973) Job Market Signalling Quarterly Journal of Economics, Vol. 87, No. 3 (Aug., 1973), pp. 355-374. Published by: The MIT

xvi. Moore, D. A., Tetlock, P. E., Tanlu, L., \&Bazerman, M. H. (2006). Conflicts of interest and the case of auditor independence: Moral seduction and strategic issue cycling. Academy of Management Review, 31(1), 10-29.

xvii. Morris, R. D. (1987). Signalling, agency theory and accounting policy choice. Accounting and business Research, 18(69), 47-56.

xviii. Mugenda (2003) Mugenda, O. M. \& Mugenda, A. G. (2003). Research methods: Quantitative and qualitative Approaches. Nairobi: African Centre for Technology Studies.

xix. Mushier (2003) Auditing: Theory and Practice, 2nd edition, Essex Pearson Education.

xx. Myers et al (2003). Fundamentals of Practical auditing, 6th edition, Eastern Economy, New Delhi, India.

xxi. O’Reilly and Caldwell (2001 Culture and Demography in Organizations Stanford Graduate School of Business 
xxii. Pigé, 2000 Auditor independence dismissal threats and the market reaction to Auditor switch Journal of accounting research vol 30 pg. 1-23

xxiii. Public Company Accounting Oversight Board (PCAOB). (2011). Concept release on auditor independence and audit firm rotation. PCAOB Release No. 2011-006.

xxiv. Quinones (2005) Does opinion shopping impair Audit quality, auditor independence Journal of Accounting research vol 44 pg. 561-583

xxv. Roush, P. B., Church, B. K., Jenkins, J. G., McCracken, S. A., \& Stanley, J. D. (2011). Auditor rotation: The PCAOB considers a new direction. Current Issues in Auditing, 5(2), C15-C20.

xxvi. Salancik, (2007); O’Reilly and Caldwell, 2001Saunders et al., 2003 Research Methods for Business Students Prentice Hall

xxvii. Saunders, M. N. (2011). Research methods for business students, 5/e. Pearson Education India.

xxviii. Schmidt et al (2006) The use of audit committee for monitoring Journal of Accounting and public policy vol13 pp121-139

xxix. Stiglitz (2002) Signalling Theory: A Review and Assessment

xxx. Sweeney, (2004) Empirical analysis of the economic demand for auditing in the initial public offering market Journal of Accounting Research vol37 225-238

xxxi. Tepalagul, N., \& Lin, L. (2015). Auditor independence and audit quality: A literature review. Journal of Accounting, Auditing \& Finance, 30(1), 101-121.

xxxii. Watts \& Zimmerman, (2006). Do Spanish firms change auditors to avoid a qualified opinion International Journal of Auditing vol7 pg3 